\title{
Front Matter: Volume 11156
}

, "Front Matter: Volume 11156," Proc. SPIE 11156, Earth Resources and Environmental Remote Sensing/GIS Applications X, 1115601 (4 November 2019); doi: $10.1117 / 12.2556518$

SPIE. Event: SPIE Remote Sensing, 2019, Strasbourg, France 


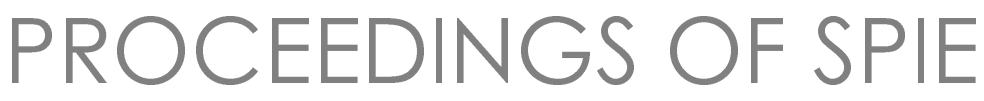

\title{
Earth Resources and Environmental Remote Sensing/GIS Applications $X$
}

\author{
Karsten Schulz \\ Ulrich Michel \\ Konstantinos G. Nikolakopoulos \\ Editors
}

10-12 September 2019

Strasbourg, France

Sponsored by

SPIE

Cooperating Organisations

European Optical Society

ISPRS - International Society for Photogrammetry and Remote Sensing

EARSeL-European Association of Remote Sensing Laboratories (Germany)

Published by

SPIE 
The papers in this volume were part of the technical conference cited on the cover and title page. Papers were selected and subject to review by the editors and conference program committee. Some conference presentations may not be available for publication. Additional papers and presentation recordings may be available online in the SPIE Digital Library at SPIEDigitalLibrary.org.

The papers reflect the work and thoughts of the authors and are published herein as submitted. The publisher is not responsible for the validity of the information or for any outcomes resulting from reliance thereon.

Please use the following format to cite material from these proceedings:

Author(s), "Title of Paper," in Earth Resources and Environmental Remote Sensing/GIS Applications $X$, edited by Karsten Schulz, Ulrich Michel, Konstantinos G. Nikolakopoulos, Proceedings of SPIE Vol. 11156 (SPIE, Bellingham, WA, 2019) Seven-digit Article CID Number.

ISSN: 0277-786X

ISSN: 1996-756X (electronic)

ISBN: 9781510630154

ISBN: 9781510630161 (electronic)

Published by

SPIE

P.O. Box 10, Bellingham, Washington 98227-0010 USA

Telephone +1 3606763290 (Pacific Time) · Fax +1 3606471445

SPIE.org

Copyright @ 2019, Society of Photo-Optical Instrumentation Engineers.

Copying of material in this book for internal or personal use, or for the internal or personal use of specific clients, beyond the fair use provisions granted by the U.S. Copyright Law is authorized by SPIE subject to payment of copying fees. The Transactional Reporting Service base fee for this volume is $\$ 21.00$ per article (or portion thereof), which should be paid directly to the Copyright Clearance Center (CCC), 222 Rosewood Drive, Danvers, MA 01923. Payment may also be made electronically through CCC Online at copyright.com. Other copying for republication, resale, advertising or promotion, or any form of systematic or multiple reproduction of any material in this book is prohibited except with permission in writing from the publisher. The CCC fee code is 0277$786 \times / 19 / \$ 21.00$.

Printed in the United States of America by Curran Associates, Inc., under license from SPIE.

Publication of record for individual papers is online in the SPIE Digital Library.

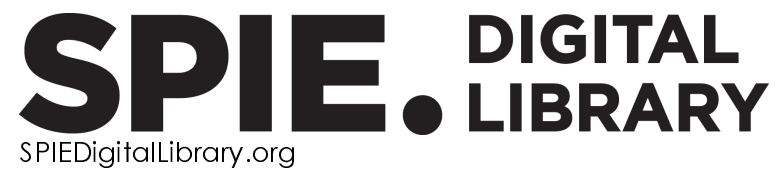

Paper Numbering: Proceedings of SPIE follow an e-First publication model. A unique citation identifier (CID) number is assigned to each article at the time of publication. Utilization of CIDs allows articles to be fully citable as soon as they are published online, and connects the same identifier to all online and print versions of the publication. SPIE uses a seven-digit CID article numbering system structured as follows:

- The first five digits correspond to the SPIE volume number.

- The last two digits indicate publication order within the volume using a Base 36 numbering system employing both numerals and letters. These two-number sets start with $00,01,02,03,04$, 05, 06, 07, 08, 09, OA, OB ... 0Z, followed by 10-1Z, 20-2Z, etc. The CID Number appears on each page of the manuscript. 


\title{
Contents
}

\author{
vii Authors \\ ix Conference Committee \\ xi Introduction
}

SENSORS AND PLATFORMS

$1115602 \quad$ New perspectives in coastal monitoring (Invited Paper) [11156-1]

1115603 Assessment of informative capability of spaced-based hyperspectral system in forest monitoring tasks [1 $11156-2]$

1115604 Instrument simulation of multispectral remote sensing images in the frame of GF-4 satellite system [1 $11156-3]$

\section{PROCESSING METHODOLOGIES I}

1115606 Analysis of the gas flare flame with IR cameras [11156-5]

1115607 Classification of post-fire recovery trajectories using Landsat time series in the Mediterranean region: Spain [1 1156-6]

1115609 Spatial downscaling of FY3B soil moisture based on MODIS land surface temperature and NDVI [11156-8]

PROCESSING METHODOLOGIES II

$11156 \mathrm{OB} \quad$ A semi-automatic approach to derive land cover classification in soil loss models (Invited Paper) [1 $11156-10]$

$111560 \mathrm{C}$ Thematic spectral remote sensing data in land covers' monitoring over test region [11156-11]

$11156 \mathrm{OE} \quad$ An assessment of support vector machine for land cover classification over South Korea [11156-13]

11156 OF Approach for generating high accuracy machine learning model for high resolution geochemical map completion using remote sensing data: case study of Arizona, USA [11156-15] 
$111560 G$ Assessment of the existing multi-hazard methods: intended for monitoring natural threats on archaeological sites [11156-16]

$11156 \mathrm{Ol} \quad$ The use of UAVs and photogrammetry for the documentation of cultural heritage monuments: The case study of the churches in Cyprus [11156-18]

\section{HAZARD MITIGATION AND GEOLOGICAL APPLICATIONS I}

11156 OK Conditioning factor determination for mapping and prediction of landslide susceptibility using machine learning algorithms [11 156-19]

$11156 \mathrm{OL} \quad$ A study on recent ground deformation near Patras, Greece [11156-20]

$111560 \mathrm{M} \quad$ Effects of variable selection on the landslide susceptibility assessment using machine learning techniques [1 $11156-22]$

\section{HAZARD MITIGATION AND GEOLOGICAL APPLICATIONS II}

1115600 Geospatial and field survey data for earthquakes multi precursors detection [11156-24]

11156 OP Remote sensing onshore hydrocarbon direct detection for exploration: why is it different? [1 $1156-25]$

$111560 Q \quad$ Evaluating the performance of support vector machines (SVMs) and random forest (RF) in Li-pegmatite mapping: preliminary results (Best Student Paper Award) [1 $1156-26]$

11156 OR Detection of coal stockpiles using geospatial satellite images [1 $1156-27]$

INFRASTRUCTURES AND URBAN AREAS

11156 OU Towards change analysis in sequences of SAR sub-aperture images [11156-30]

\section{ENVIRONMENTAL MONITORING CONCEPTS I}

11156 OY A Sentinel-2 unsupervised forest mask for European sites [1 $1156-34]$

$11156 \mathrm{OZ}$ Coastal monitoring activities in the frame of TRITON project [1 1156-35]

iv 
1115610 The use of satellite remote sensing and UAV for the mapping of coastal areas for the use of marine spatial planning [1 $11156-36]$

\section{ENVIRONMENTAL MONITORING CONCEPTS II}

1115611 Synergy of Copernicus optical and radar data for oil spill detection [11156-37]

1115612 On the effects of different groundwater inventory scenarios for spring potential mapping in Haraz, northern Iran [1 $11156-38]$

1115615 Application of remotely sensed NDVI and soil moisture to monitor long-term agricultural drought [1 $11156-42]$

\section{POSTER SESSION}

1115619 Studying the coastal landslides processes by InSAR [11156-21]

11156 1A Satellite thermal IR imagery for accessing the environmental impact of transportation [11156-45]

11156 1B Seismic vulnerability assessment and mapping using frequency ratio and logistic regression: a case study of Gyeongju, South Korea [1 $1156-46]$

11156 1C Monitoring of vegetation variation in Jiangsu province based on MODIS-LAI data [1 $1156-47]$

11156 1D Sub-pixel matching data of environmental remote sensing in the monitoring of natural resources [1 $11156-48]$

$11156 \mathrm{IE} \quad$ Comparing different techniques of satellite imagery classification to mineral mapping pegmatite of Muiane and Naipa: Mozambique [1 $1156-49]$

$11156 \mathrm{IF} \quad$ Remote sensing techniques to detect areas with potential for lithium exploration in Minas Gerais, Brazil [1 1156-50]

11156 1G Effect of urban surface albedo on thermal environment characterization [11156-51]

11156 1H Impact of marine heatwaves on chlorophyll: a variability using Geostationary Ocean Color Imager (GOCI) [1 $11156-52]$

$111561 \mathrm{~J} \quad$ Land cover segmentation of aerial imagery using SegNet [11156-54]

11156 1N An automatic Sentinel-2 forest types classification over the Roncal Valley, Navarre: Spain [11156-58]

1115610 Continuous coastal monitoring using UAV photogrammetry [11156-59] 
11156 1P Development of snowplow operation support system using GNSS and QZSS [11156-60]

$111561 Q \quad$ Satellite remote sensing of chlorophyll and Secchi depth for monitoring lake water quality: a validation study [1 $11156-61]$ 


\section{Authors}

Numbers in the index correspond to the last two digits of the seven-digit citation identifier (CID) article numbering system used in Proceedings of SPIE. The first five digits reflect the volume number. Base 36 numbering is employed for the last two digits and indicates the order of articles within the volume. Numbers start with 00, 01, 02, 03, 04, 05, 06, 07, 08, 09, 0A, 0B...0Z, followed by 10-12, 20-2Z, etc.

Aguado, Inmaculada, 07

Ahmadi, Parisa, 12

Al-Najjar, Husam Abdulrasool Hammadeh, OK, 12

Atanasova, Mila, 19

Baldina, Elena A., 1A

Boldt, Markus, OU

Borch, Jörg, 06

Borisova, Denitsa, OC

Cadario, Erich, OU

Cardoso-Fernandes, J., OQ, IF

Chowdhary, Abhijeet, OR

Christodoulou, Dimitris, $\mathrm{OZ}$

Contractor, Gopali, OR

Cunha, M., OB

de la Fuente, D., OY, $1 \mathrm{~N}$

Depountis, Nikolaos, $\mathrm{OZ}$

Dimitrov, Ventzeslav, OC

Dmitriev, Y. V., 03

Dodamani, B. M., 15

Du, Yingkun, $1 C$

Duarte, L., OB

Dubucq, D., OP

Ebner, A., OP

Evagorou, E., Ol, 10

Evers, Madeline, OL

Fakiris, Elias, 02, $0 Z$

Fernandez-Carrillo, A., OY, $1 \mathrm{~N}$

Fetisov, D. V., 1D

Fetisova, T. A., 1D

Fischer, Christian, 06

Franco-Nieto, A., OY, $1 \mathrm{~N}$

Fujii, Nobuyuki, 1P

García, Mariano, 07

Gawade, Pallavi, OR

Gemusse, Ubaldo, 1E

Gibril, Mohamed Barakat A., 12

Goranova, Margarita, OC

Hadjimitsis, Diofantos G., 0G, 0I, 10

Halin, Alfian Abdul, 12

Han, Jihye, OE, OM, 1B, 1 J, 10

$\mathrm{He}$, Hongyan, 04

Heege, Thomas, 1Q

Hristova, Valentina, OC

Huang, Chenhui, OF

Jadhav, Akash M., OR

Jagyasi, Bhushan, $\mathrm{OR}$

Jaiswal, Abhishek, OR

Jiang, Cheng, 04

Kalantar, Bahareh, 0K, 12
Karle, Nathalie, $1 Q$

Kavoura, Katerina, $\mathrm{OZ}$

Kim, Jinsoo, OE, OM, 1B, $1 \mathrm{~J}, 10$

Kim, Seongheon, OE, OM, 1B, 1 J, 10

Klinger, Philip, 1Q

Kolesenkov, A. N., 1D

Konishi, Tomohisa, 1P

Konstantinopoulos, Dimitris, $\mathrm{OZ}$

Kyriou, Aggeliki, OL, 11

Lee, Seonghyeok, OE, OM, 1B, 1 J, 10

Lee, Seonju, $1 \mathrm{H}$

Lima, Alexandre, $0 Q, 1 E, 1 F$

Lin, Yifan, $1 \mathrm{C}$

Liu, Jingjing, $1 \mathrm{C}$

Ma, Zhongqi, 04

Mateciuc, Doru N., 00

Mettas, C., Ol, 10

Mohammad, Nasiruddin, OR

Mukherjee, Bolaka, OR

Nikolakopoulos, Konstantinos G., 02, OL, 0Z, 11

Nikolov, Hristo, 0C, 19

Otremba, Frank, 06

Papageorgiou, Nikoletta, OG

Papatheodorou, George, 02, $0 Z$

Park, Myung-Sook, $1 \mathrm{H}$

Park, Soyoung, OE, OM, 1B, 1 J, 10

Pathak, Abhishek A., 15

Pradhan, Biswajeet, OK

Rao, Peng, 09

Reulke, Ralf, 06

Rivas-Gonzalez, F. W., OY, $1 \mathrm{~N}$

Roda-Robles, E., $0 Q$

Sabatakakis, Nikolaos, $0 Z$

Saeidi, Vahideh, OK

Salas, Javier, 07

Santos, D., IF

Sardelianos, Dimitris, 02

Säuberlich, Thomas, 06

Savastru, Dan M., 00, $1 \mathrm{G}$

Savastru, Roxana S., 0O, $1 \mathrm{G}$

Schenk, Karin, 1Q

Schulz, Karsten, OL, IQ

Shah, Urvi, OR

Sheng, Jiahui, 09

Shibanov, S. Y., 03

Shibuya, Akinobu, OF

Son, Sanghun, OE, OM, 1B, $1 \mathrm{~J}, 10$

Soszynska, Agnieszka, 06

Strotov, V. V., ID 
Suga, Yuzo, 1P

Teodoro, Ana Claudia Moreira, OB, OQ, 1E, IF

Themistocleous, Kyriacos, 0G, 0I, 10

Ueda, Naonori, 12

Vegesna, R.G. Varma, OR

Viana-Soto, Alba, 07

Wang, Jing, $1 C$

Wolf, Thomas, 1Q

Yuan, Xinyi, 1C

Zhu, Hanlu, 09

Zisimopoulos, Miltiadis, 11

Zoran, Liviu Florin V., $1 \mathrm{G}$

Zoran, Maria A., 00, $1 \mathrm{G}$

Zotov, S. A., 03 


\section{Conference Committee}

Symposium Chairs

Christopher M. U. Neale, University of Nebraska Lincoln (United States) and Daugherty Water for Food Institute (United States)

Karsten Schulz, Fraunhofer-Institut für Optronik, Systemtechnik und Bildauswertung IOSB (Germany)

Conference Chair

Karsten Schulz, Fraunhofer-Institut für Optronik, Systemtechnik und Bildauswertung IOSB (Germany)

Conference Co-chairs

Ulrich Michel, Jade Hochschule (Germany)

Konstantinos G. Nikolakopoulos, University of Patras (Greece)

Conference Programme Committee

Markus Boldt, Fraunhofer-Institut für Optronik, Systemtechnik und Bildauswertung IOSB (Germany)

Dimitri Bulatov, Fraunhofer-Institut für Optronik, Systemtechnik und Bildauswertung (Germany)

Pierre Karrasch, Technische Universität Dresden (Germany)

Pablo H. Rosso, Leibniz-Zentrum für Agrarlandschaftsforschung (ZALF) e.V. (Germany)

Ana Claudia Moreira Teodoro, Universidade do Porto (Portugal) Kyriacos Themistocleous, Cyprus University of Technology (Cyprus) Christine Wessollek, Technische Universität Dresden (Germany)

Session Chairs

1 Sensors and Platforms

Karsten Schulz, Fraunhofer-Institut für Optronik, Systemtechnik und Bildauswertung IOSB (Germany)

2 Processing Methodologies I

Karsten Schulz, Fraunhofer-Institut für Optronik, Systemtechnik und Bildauswertung IOSB (Germany)

3 Processing Methodologies II

Pierre Karrasch, Technische Universität Dresden (Germany) 
4 Remote Sensing for Archaeology, Preservation of Cultural and Natural Heritage

Kyriacos Themistocleous, Cyprus University of Technology (Cyprus)

5 Hazard Mitigation and Geological Applications I

Konstantinos G. Nikolakopoulos, University of Patras (Greece)

6 Hazard Mitigation and Geological Applications II

Konstantinos G. Nikolakopoulos, University of Patras (Greece)

7 Infrastructures and Urban Areas

Markus Boldt, Fraunhofer-Institut für Optronik, Systemtechnik und Bildauswertung IOSB (Germany)

8 Environmental Monitoring Concepts I

Christine Wessollek, Technische Universität Dresden (Germany)

9 Environmental Monitoring Concepts II

Ana Claudia Moreira Teodoro, Universidade do Porto (Portugal) 


\title{
Introduction
}

This proceedings volume is a collection of papers based on the invited and contributed presentations introduced at the SPIE conference, Earth Resources and Environmental Remote Sensing/GIS Applications X formerly known under the title, Remote Sensing for Environmental Monitoring, GIS Applications, and Geology. The conference took place in Strasbourgh, France from 10 September to 12 September 2019. It was the nineteenth conference with this topic after its inauguration in Toulouse, France, in 2001 . More than 40 papers were presented at this conference.

The conference sessions with presented papers and interactive posters were grouped into the following themes: Sensors and Platforms, Processing Methodologies, Remote Sensing for Archaeology, Preservation of Cultural and Natural Heritage, Hazard Mitigation Geologic Applications, Infrastructures and Urban Areas and Environmental Monitoring Concepts. Lively discussions often continued into the coffee breaks especially related to the latter topics. Although the session topics seems to be rather diverse, the multidisciplinary community of this conference allows discussion of important topics from several interesting points of view. After all, there was a strong support from the audience to continue these themes in future conferences. The topics of machine learning and deep learning were featured in several presentations and will play stronger roles in our conference. The keynote presentation, "New perspectives in coastal monitoring" revealed that not only flying unmanned vehicles plays an interesting role in our research.

The paper submission and review processes were again perfectly organized by the SPIE staff. We would also like to thank the SPIE staff for their responsiveness and support on-site. We are also grateful to the Program Committee members for their help in the review and session compilation process.

\author{
Karsten Schulz \\ Ulrich Michel \\ Konstantinos G. Nikolakopoulos
}


Proc. of SPIE Vol. 11156 1115601-12

Downloaded From: https://www.spiedigitallibrary.org/conference-proceedings-of-spie on 26 Apr 2023 Terms of Use: https://www.spiedigitallibrary.org/terms-of-use 